УДК 373.5.017.4

DOI: https://doi.org/10.35619/iiu.v0i9.116

Сойчук Руслана

доктор педагогічних наук, доцент, завідувач кафедри педагогіки початкової освіти

Рівненського державного гуманітарного університету, м.Рівне, Україна

ORCID: 0000-0001-5559-5388

e-mail: ruslanasoichuk@gmail.com

\title{
ТЕОРЕТИКО-ПРИКЛАДНИЙ АСПЕКТ ВИХОВАННЯ НАЦІОНАЛЬНОЇ СОЛІДАРНОСТІ В УЧНІВСЬКОЇ МОЛОДІ
}

\begin{abstract}
Анотація. У статті розглянуто вагомість проблеми виховання національної солідарності в учнівської молоді як основи національного самоствердження та запоруки консолідації української нації. 3'ясовано, що у кризовий період націєстановлення змінюється система національних цінностей та загострюється потреба у формуванні позитивної національної ідентичності й національному згуртуванні задля подальшого національного самоствердження кожної особистості громадянина та української держави. Проаналізовано різні погляди учених на сутність поняття «національна солідарність» у руслі вітчизняних та зарубіжних досліджень. Схарактеризовано основні принципи організації процесу виховання національної солідарності в учнівської молоді в умовах закладу ЗСО. Визначено основні характеристики і завдання, особливості й умови ефективної взаємодії педагога й учнів. Представлено традиційні та інтерактивні форми і методи виховної роботи зі школярами, які забезпечують цілісний системний підхід до організації процесу виховання національної солідарності в учнівської молоді в позаурочній діяльності.
\end{abstract}

Ключові слова: національна солідарність, національна ідентичність, національні цінності, учнівська молодь, українська нація, форми і методи виховання.

Постановка проблеми. У час зовнішньополітичної загрози й викликів сьогодення, складних реалій державотворення та націєстановлення подальший поступ української держави детермінований гармонійним узгодженням загальнолюдських i національних цінностей як основи національного самоствердження та запоруки консолідації української нації.

У кризовий період зазнає змін система цінностей національної спільноти, що посилює значення для української нації національного самоствердження як такого, що інтегрує спектр домінантних цінностей - національні солідарність, гідність і гордість, відповідальність, толерантність, - які творять українську позитивну національну ідентичність як основу згуртування та єдності нації. Адже національне згуртування, як стверджує В. Кремень, сприяє «ефективнішому відстоюванню національних інтересів у відносинах з іншими державами, що є надзвичайно актуальним», та заможнішому життю громадян (Кремень, 2010, с. 542).

Це знайшло своє відображення в основних положеннях Закону України «Про освіту», Указі Президента України «Про Стратегію національнопатріотичного виховання дітей та молоді на 2016-2020 роки», Концепції 
національно-патріотичного виховання дітей та молоді, Концепції «Нова українська школа» та в інших нормативно-правових документах.

Тому нині стратегічним напрямом діяльності держави, суспільства, зокрема закладів освіти і виховання, має стати розвиток національно свідомого громадянина України як держави. 3 огляду на це, заклад загальної середньої освіти, відповідно до особистісно орієнтованої освітньої парадигми, повинен сприяти становленню нового українця зі сформованою позитивною національною ідентичністю, здатного до національної солідарної взаємодії 3 іншими представниками нації для відстоювання інтересів української держави.

Аналіз останніх досліджень 3 проблеми. Чільне місце посідають наукові здобутки учених, у яких відображено окремі питання досліджуваного феномену, зокрема: психологічні аспекти національно-особистісних цінностей, механізми їх прояву в повсякденній життєдіяльності вихованців (схарактеризовано І. Бехом, I. Булах, В. Крисько, Л. Снігур, Л. Співак та іншими); розвиток процесів національної ідентифікації та іiі вплив на формування самодостатньої особистості (досліджено у роботах Л. Клочек, Г. Філіпчука, Л. Шимченко та інших); специфіка національно-патріотичного виховання, а саме, формування національної свідомості та самосвідомості (окреслено М. Боришевським, О. Вишневським та іншими науковцями).

Однак попри значний інтерес учених до досліджуваного феномену, недостатньо вивченими залишаються теоретичні та практичні аспекти виховання національної солідарності в учнівської молоді, що наразі $\epsilon$ об'єктивною потребою та метою пропонованої статті.

Виклад основного матеріалу дослідження. Доцільно зауважити, що формування національної ідентичності як колективного феномену має відзначатися зорієнтованістю на творення єдності, національної солідарності, толерантності, на досягнення консолідації української нації. Тому видається раціональним вироблення механізмів трансформації національної ідентичності в контексті європейської інтеграції на засадах-цінностях толерантності та національної солідарності. Національна солідарність постає рушійною силою «індивідуальної суспільно-історичної активності особистості, визначає дійсний рівень ії національної автентичності як наслідку процесу національної самоідентифікації» (Лавриченко, 2000, с. 288), що надає рішучості долати труднощі, жити й творити майбутнє своє й української нації; гуртує громадян на різні форми боротьби за національне і соціальне визволення (Кремень, 2010, c. 157), оскільки «тільки так ми маємо шанс подолати взаємне відчуження генерацій і верств народу і попри все поновити тяглість культури і цілісність нації» (Лавриченко, 2000, с. 282).

Розглядаючи поняття «солідарність», натрапляємо на таке його трактування: активне співчуття яким-небудь діям, думкам; спільність поглядів, інтересів; спільна відповідальність (Ковальова та Корига, 2002, с. 560); такий стан взаємодії між людьми, у якому виникає злагоджене розуміння та сприйняття світу без насильства, де людина сприймається як найвища цінність, яка обумовлена свободою (Кремень, 2010, с. 177-178); одностайність, спільність інтересів, активне співчуття певним діям або судженням; соціальна згуртованість, єдність дій, спільна діяльність, у процесі якої досягають певних цілей, вирішують суспільні проблеми, реалізовують спільні інтереси (Сазонов, 2001, c. 615). 
Водночас національна солідарність інтегрує переконання та дії, взаємодопомогу та підтримку членів певної соціальної групи, національної спільноти на основі спільності інтересів, зокрема національних інтересів держави, нації, та необхідності досягнення загальних цілей; спільної відповідальності; активного співчуття та підтримку актуально доречних інтересів чи думок (Осипов, 1995). Зокрема, усвідомлення потреби бути солідарними із представниками різних національних спільнот задля процвітання української нації у своїх відповідях продемонстрували 58,3 \% учнівської молоді; не визначились - 21,9 \% опитаних. 19,8 \% школярів переконані в раціональності досягати успіху лише задля власних інтересів. 48,7 $\%$ опитаних згідні 3 твердженням, що шляхом їхнього особистого самовдосконалення як носіїв цінностей української нації вони здатні поліпшити добробут народу, 25,8 \% учнів не визначились, а 25,5 \% опитаних визнають доцільність самовдосконалення лише з особистою метою. Цілковито приймають національні цінності, традиції та культуру українського народу 65,8 \% учнів, не можуть визначитись 19,2 \% школярів, керуються у своїй поведінці лише умовностями поведінки в соціумі 15,0 \% учнів (Сойчук, 2016).

Процес виховання національної солідарності в учнівської молоді постає на грунті міжособистісної суб'єкт-суб'єктної взаємодії його учасників у контексті спільної діяльності, охоплює формування рівноправного спілкування 3 урахуванням міркувань інших і визнання права на відмінні судження. Дотримання принципу суб'єкт-суб'єктної взаємодії у спілкуванні та співпраці вихователя й вихованця сприяє вияву емпатії, національної рефлексії та ідентифікації, творчого потенціалу, здатності до гуманної поведінки та ствердженню активної громадянської позиції. Доповнення принципу суб'єктсуб'єктної взаємодії науковими положеннями про спільний учинок передбачає усвідомлюваний, цілеспрямований i водночас спонтанний життєвий акт особистостей, що має на меті вільне бажання взаємообміну існуючими душевними i духовними ресурсами та взаємоузгоджене творення нових цінностей і смислів індивідуального і національного буття (Татенко, 2015, с. 51).

Дотримання вищеназваного принципу в поєднанні із принципом національної консолідації на гуманістичних засадах уможливлює формування ціннісного ставлення до Іншого у полікультурному українському суспільстві та розуміння й усвідомлення потреби становлення української громадянської нації. У цьому контексті особливе значення відводиться вмінню вибудовувати під час різних видів позаурочної діяльності закладів ЗСО міжособистісну та міжнаціональну взаємодію, зорієнтовану на досягнення національного успіху. Переживання духу партнерства, єдності й національної солідарності у спільній колективній діяльності передбачає принцип колективної активності, зумовлений формуванням активної життєвої позиції, толерантності, норм гуманної поведінки й розуміння та прийняття Іншого, креативності, справедливості щодо себе й інших, здатності до самоконтролю, саморегуляції в особистісному колективі, де кожен $є$ унікальним і незамінним, а також співпрацею задля досягнення спільного успіху як результату індивідуального чи колективного досягнення (Бех, 2008).

Отже, реалізація означених принципів у процесі виховання учнівської молоді передбачає формування вмінь національної солідарної взаємодії «як інструменту підтримання стосунків для економічної і соціальної інтеграції в 
багатонаціональному та багатокультурному суспільстві» (Савченко, 2011, с. 5), розвиток здатностей до емпатії, національної рефлексії та ідентифікації, корекції національного самооцінювання, почуття власної і національної гідності та шанобливого ставлення до досягнень представників як своєї нації, так й інших національних спільнот, національної саморегуляції та афіліації.

У цьому контексті істотною $\epsilon$ позиція про національну солідарну взаємодію, що передбачає єдність поглядів, переконань, національних почуттів та прагнень, національних цінностей, національних інтересів і відповідальність за спільну діяльність усіх суб'єктів виховного процесу, що спрямована на досягнення мети (Сойчук, 2016).

Виховна взаємодія $є$ процесом безпосереднього або опосередкованого впливу суб'єктів один на одного, що $\epsilon$ основою їхнього саморуху й саморозвитку та визначається виникненням взаємозв'язків унаслідок взаємозумовленості (Степанов, 2006). Зокрема виокремлюються такі види взаємодії: співпраця (кооперація) - передбачає паритетні умови досягнення цілей кожного суб'єкта діяльності, що сприяє реалізації мети іншого; суперництво (конкуренція) - визначається досягненням мети суб'єктом діяльності з певними ускладненнями чи унеможливленням досягнення цілі; конфлікт - характеризується зіткненням інтересів, цілей та позицій суб'єктів взаємодії (Шапар, 2004).

У дослідженні враховано такі основні характеристики взаємодії: взаємопізнання, взаєморозуміння, взаємоставлення, взаємодія, взаємовплив. Водночас узято до уваги й те, що всі зазначені характеристики взаємодії взаємопов'язані й взаємообумовлені та розкриваються через спрацьованість (злагодженість, солідарність) i сумісність. Спрацьованість характеризує сумісну діяльність людей з позиції ії успішності: кількості, якості, швидкості, оптимальної координації дій іiі учасників, що базується на взаємній співдіяльності, проявляється мінімальними емоційними виявами. Сумісність розглядається як максимально можлива задоволеність учасників один одним із потужними емоційно-енергетичними витратами на взаємодію та високим ступенем когнітивної ідентифікації (Обозов, 1981).

Виховання національної солідарності в учнівської молоді, ефективна взаємодія педагога та учнів передбачають: сформованість позитивної установки на спільну діяльність (усвідомлення іiі мети й особистісний смисл; спільне планування, організація та підбиття підсумків); педагогічну доцільність розподілу ролей та функцій; створення ситуацій вільного вибору видів і способів діяльності. При цьому позиція педагога сприяє самореалізації, самовизначенню та самоствердженню кожного вихованця в різних видах діяльності (Рожков, Байбородова, 2000, с. 47-48).

Виховання в учнівської молоді почуття національної солідарності, толерантності в колективі, громаді та поваги до іншої особистості передбачає вирішення таких завдань: формувати здатність до національної солідарної взаємодії з Іншими та в колективі; досягати реалізації власних потреб та інтересів у колективі на взаємоприйнятих умовах відносин та дій, визначати пріоритетні інтереси колективу в досягненні поставленої цілі, керуватися суспільно значущими соціальними й морально-духовними цінностями; виявляти емпатію, співчуття, співпереживання, уміння радіти за досягнення успіху Іншого та поділяти свій успіх з Іншими, а також дарувати щастя іншим; 
формувати уміння передбачати можливі міжособистісні та міжнаціональні конфлікти та уникати їх, при виникненні - вирішувати.

За таких умов діяльність педагога зорієнтована на згуртування особистісного колективу, у якому кожен вихованець $\epsilon$ унікальним i незамінним, у якому всі відчувають потребу один в одному (Бех, 2008, с. 226). Така діяльність спрямована на досягнення цілей, що виходять за межі групових цінностей, та передбачає насамперед участь усіх вихованців у самоуправлінні та суспільно значущих видах діяльності.

Досвід роботи засвідчив, що виховання успіхом сприяє згуртуванню колективу, а також дотриманню й керуванню розвитком його унікальних виховних можливостей: блокування агресивних виявів вихованця; виховний вплив індивідуальності в колективі; мінімізація внутрішнього опосередкування міжособистісного впливу в класному колективі; емоційний захист; соціальне середовище самореалізації; формування особистісної ідентичності; тактика самопрезентації; каталізатор соціальних настановлень вихованців (Бех, 2008, с. 345-348).

Організація кооперативної діяльності в колективі передбачає як мету, так i результат спільними. За такої діяльності кожен іiі учасник здійснює свій внесок у «спільне досягнення-продукт», що знімає проблему формування i прояву конфліктності й конкуренції, а натомість мотивує до співпраці та злагоди. Саме кооперативна діяльність створює умови для виховання групового почуття корисності Іншого, що сприяє єднанню вихованців. Водночас характерним для такого виду діяльності $є$ прояв групового впливу на особистість, зокрема: механізм емоційного зараження, ідентифікації, відповідальності за групу та за себе (Бех, 2008, с. 646-647).

Розвиток кооперованих навичок й умінь учнівської молоді здійснюється під час роботи в команді, у колективних творчих справах, а також у групових дослідженнях, іграх, «графіті», «кутів» та ін. Різні види діяльності передбачають формування таких кооперованих навичок: формувальних первинних, які $\epsilon$ засадничими для ефективного функціонування групи (перебування з групою, підбадьорювання, сприяння тощо); функціональних необхідних для участі у груповій роботі (висловлення підтримки, пояснення, прохання про допомогу, надання допомоги тощо); рольових - уміннях, необхдних для виконання різних ролей (аналізувати та підбивати підсумки, збирати інформацію, пояснювати тощо) (Джонсон, 1989).

3 метою реалізації зазначених умов передбачено такі види діяльності: психологічний практикум: «Вчимося розуміти іншого», «Особистість та іiі емоційні почуття», «Я і колектив», «Барви життя», «Радість за себе і за іншого»; години спілкування: «Людина - найвища цінність», «Колектив i особистість», «Вміти розмовляти, вміти слухати», «Інший - теж особистість», «Чи потрібно бути толерантним?»; тренінг «Вчимося комунікації», «Вчимося бути Людиною»; твір-есе «Хто вона, справжня Людина?», «Вчимося радіти за успіхи Іншого», «Вчимося довіряти»; усний журнал «Спілкування - це...», «Радість і вболівання за успіхи Іншого»; диспут «Причини конфлікту в колективі», «Радість чи заздрість?»; «Я, Ти, Інший у колективі», «Вміти вибачати», «Розділити успіх»; акції «Допоможи дитині», «Подаруй щастя іншому»; рейди «Привітання до свята»; інформаційне повідомлення «Бути толерантним...»; написання літопису класу, створення фотокниги; акції 
«Допоможи дитині», «Подаруй щастя іншому»; лекції «Талант, праця, успіх», «Основи мистецтва колективної взаємодії» та ін. (Сойчук, 2016).

Результати дослідження переконливо доводять, що перманентні переживання позитивних емоцій, радості від зробленої корисної справи для оточення (рідних, знайомих, громади, друзів, сторонніх людей) сприяють тому, що учні поступово звикають відчувати настрій Іншого, радіти за його успіхи, співчувати та допомагати у кризових ситуаціях (Боришевський, 1995).

У вихованні національної солідарності в школярів дієвими $є$ виховні ситуації - спеціально організовані педагогічні умови виховання в учнівської молоді мотивів позитивної поведінки чи подолання негативних проявів, які застосовуються під час організації різного виду діяльності. Корисність виховної ситуації полягає в максимальній мобілізації особистісних зусиль задля здійснення вибору та віднайдення шляхів вирішення на основі аналізу проблеми, емпатії та рефлексії. Зокрема, використовуються такі різновиди виховних ситуацій: вербальні - побудовані на афористичних висловлюваннях, розповідях, сюжетах та реальних і нереальних подіях; конфліктні - базовані на актуалізованих проблемах, потрясіннях, психологічних зривах i непорозуміннях; уявні - створені певні умови для проведення самоаналізу й самооцінки поведінки чи події тощо; ситуації-задачі, ситуації-вправи - аналіз й обговорення проблемних елементів ігрової ситуації для подальшого спонукання вихованців до моральних дій і вчинків (Шкільна, 2014). Такі виховні ситуації, створені на засадах особистісно орієнтованого виховання, ставлять перед вихованцем зрозумілі й посильні вимоги відповідно до вікових особливостей учнівської молоді.

Позаурочна діяльність охоплює заходи, спрямовані на виховання національної солідарності, утвердження національного українського духу i шанобливе ставлення до цінностей родини та української нації. Зокрема, цьому сприяє проведення з учнівською молоддю: бесіди під час годин спілкування за такою тематикою: «Трагічні сторінки історії української державності», «Національні символи України: історія та сьогодення», «Видатні постаті України», «Гордість нашого міста (села)»; «Національні цінності українського народу», «Національна ідея: шляхи і засоби іiі реалізації», «Геноцид нації», «Дзвони Чорнобиля», «Манкурти - хто чи що?», «Народження нації» та ін.; сімейні свята у формі: квестів, творчих конкурсів «Мода по-українському», конкурси декламаторів, поетів, художників «Сучасний портрет Кобзаря», конкурс на кращий твір-роздум «Кобзар у моїй родині», конкурси творчих квіткових проектів «Краса рідного краю» (Сойчук, 2016).

Такі форми роботи сприяють цілісному уявленню про багату культуру українського народу, іiї самодостатність, цінність української нації та родини, формують почуття належності до української нації, національної солідарності та національної гідності й гордості за ії історію, здобутки, внески видатних історичних постатей та сучасників у вітчизняний та світовий розвиток.

Висновки і перспективи подальших розвідок. Отже, здійснений теоретичний аналіз дає змогу зробити висновок про те, що виховання національної солідарності в учнівської молоді визначено як організовану суб'єкт-суб'єктну взаємодію, спрямовану на духовний розвиток особистості учня, його позитивних національних почуттів і національних цінностей, що становлять внутрішню основу готовності до національного самоствердження. Відтак, гармонійне поєднання традиційних та інтерактивних форм і методів 
виховної роботи зі школярами забезпечує цілісний системний підхід до організації процесу виховання національної солідарності в учнівської молоді.

Перспективи подальших наукових розвідок вбачаємо у розробці технології виховання національної солідарності в дітей та молоді 3 урахуванням особливостей міжособистісних стосунків на певних вікових етапах.

\section{СПИСОК ВИКОРИСТАНИХ ДЖЕРЕЛ:}

Кремень В. (2010). Філософія національної ідеї : Людина. Освіта. Соиіум. 2-ге вид. Київ: Грамота. 576 с.

Лавриченко Н. (2000). Педагогіка сочіалізації: європейські абриси. Київ: ВіРА IНСАЙТ. 444 c.

Ковальова Т., Корига Л. (2002). Тлумачний словник украӥнської мови: 14000 слів і словосполучень. Харків: Синтекс. 672 с.

Сазонов И. (2001). Политология: учеб. пособие для вузов. Харьков: Фолио. $831 \mathrm{c}$.

Осипов Г. (1995). Энииклопедический соџиологический словарь. Москва: Наука. 940 c.

Сойчук Р. (2016). Виховання начіонального самоствердження в учнівської молоді. Рівне: О. Зень. 416 с.

Татенко В. (2015). Феномен соціалізації в контексті суб'єктно-вчинкового підходу. Педагогіка і психологія. № 3. С. 44-51.

Бех І. (2008). Виховання особистості : підручник. Київ: Либідь. 848 с.

Савченко О. (2011). Ключові компетентності - інноваційний результат шкільної освіти. Рідна школа. № 8/9. сс. 4-8.

Степанов О. (2006). Психологічна енциклопедія. Київ: Академвидав. 424 с.

Шапар В. (2004). Психологічний тлумачний словник. Харків: Прапор. 640 с.

Обозов Н. (1981). О трехкомпонентной структуре межличностного взаимодействия. Психология межличностного познания. Москва: Педагогика. сс. 80-92.

Рожков М.,Байбородова Л. (2000). Организация воспитательного процесса в школе: учеб. пособие для студ. высш. учеб. заведений. Москва: ВЛАДОС. 256 с.

Johnson D. (1989). Coperation and competition: Theory and research. Edina, MN Interaction Book Company. 253 p.

Боришевський М. (1995). Сімейне виховання як гарант морального становлення особистості.Початкова школа. № 4. сс.4-9.

Шкільна I. (2014). Виховання культури гідності стариих підлітків у позаурочній діяльності. Кіровоград: Імекс-ЛТД. 32 с.

\section{REFERENCES:}

Kremen, V. (2010). Filosofiia natsionalnoi idei: Liudyna. Osvita. Sotsium. [Philosophy of the National Idea: Man. Education. Socium]. 2-he vyd. Kyiv: Hramota. 576 s. [in Ukrainian]

Lavrychenko, N. (2000). Pedahohika sotsializatsii: yevropeiski abrysy. [Pedagogics of Socialization: European Outlines]. Kyiv: ViRA INSAIT. 444 s. [in Ukrainian]

Kovalova, T., Koryha, L. (2002). Tlumachnyi slovnyk ukrainskoi movy: 14000 sliv $i$ slovospoluchen. [Explanatory Dictionary of the Ukrainian Language: 14,000 Words and Phrases]. Kharkiv: Synteks. 672 s. [in Ukrainian]

Sazonov, I. (2001). Politologiya: ucheb. posobiye dlya vuzov. [Political Science: textbook for Universities]. Kharkov: Folio. 831 s. [in Russian] 
Osipov, G. (1995). Entsiklopedicheskiy sotsiologicheskiy slovar. [Encyclopedic Sociological Dictionary]. Moskva: Nauka. 940 s. [in Russian]

Soichuk, R. (2016). Vykhovannia natsionalnoho samostverdzhennia v uchnivskoi molodi. [Formation of National Self-affirmation of Students' Youth]. Rivne: O. Zen. 416 s. [in Ukrainian]

Tatenko V. (2015). Fenomen sotsializatsii v konteksti subiektno-vchynkovoho pidkhodu [The Phenomenon of Socialization in the Context of Subjective-behavioral Approach]. Pedahohika i psykholohiia. No 3. S. 44-51.

Bekh, I. (2008). Vykhovannia osobystosti: pidruchnyk. [Personality Upbringing: textbook]. Kyiv: Lybid. 848 s. [in Ukrainian]

Savchenko, O. (2011). Kliuchovi kompetentnosti - innovatsiinyi rezultat shkilnoi osvity. [Key Competencies as an Innovative Result of School Education]. Ridna shkola. No 8/9. ss. 4-8. [in Ukrainian]

Stepanov, O. (2006). Psykholohichna entsyklopediia. [Psychological Encyclopedia]. Kyiv: Akademvydav. 424 s. [in Ukrainian]

Shapar, V. (2004). Psykholohichnyi tlumachnyi slovnyk. [Psychological Explanatory Dictionary]. Kharkiv: Prapor. 640 s. [in Ukrainian]

Obozov, N. (1981). O trekhkomponentnoy strukture mezhlichnostnogo vzaimodeystviya. [On the Three-component Structure of Interpersonal Interaction]. Psikhologiya mezhlichnostnogo poznaniya. Moskva: Pedagogika. ss. 80-92. [in Russian]

Rozhkov, M.. Bayborodova, L. (2000). Organizatsiya vospitatelnogo protsessa $v$ shkole: ucheb. posobiye dlya stud. vyssh. ucheb. zavedeniy. [Organization of Educational Process at School: manual for students of higher educational institutions]. Moskva: VLADOS. 256 s. [in Russian]

Boryshevskyi, M. (1995). Simeine vykhovannia yak harant moralnoho stanovlennia osobystosti. [Family Upbringing as a Quarantor for the Moral Development of the Personality]. Pochatkova shkola. No 4. ss.4-9. [in Ukrainian]

Shkilna, I. (2014). Vykhovannia kultury hidnosti starshykh pidlitkiv u pozaurochnii diialnosti. [Formation of the Culture of Dignity of Senior Teenagers in Extracurricular Activities]. Kirovohrad: Imeks-LTD. 32 s. [in Ukrainian]

\title{
THEORETICAL AND APPLIED ASPECT OF FORMATION NATIONAL SOLIDARITY AMONG SCHOOL STUDENTS
}

\author{
Ruslana Soichuk \\ Doctor in Pedagogy, Associate Professor, \\ Professor at the Department of Primary Education Pedagogy, \\ Rivne State University of the Humanities \\ Rivne, Ukraine \\ ORCID: 0000-0001-5559-5388 \\ e-mail: ruslanasoichuk@gmail.com
}

\begin{abstract}
The article considers the urgency of the problem of forming national solidarity among school youth as a basis for national self-affirmation, as well as securing the guarantee of the Ukrainian nation. It has been established that during the crisis period of nation-establishment the system the national values is changing and the need for the formation of a positive national identity and national unification for the further national self-affirmation of each citizen and the Ukrainian state is exacerbated. Different views of scientists on the essence of the concept of "national solidarity" in the context of national and foreign studies are analyzed. The basic principles of the organization of the national solidarity educational process among school youth in the conditions of the general secondary schools are determined.
\end{abstract}


It has been found that national solidarity interaction includes the unity of views, beliefs, national feelings and aspirations, national values, national interests and responsibility for the common activity, which is aimed at achieving the goal, of all subjects of the educational process. The basic characteristics and tasks, peculiarities and conditions of effective interaction between teacher and students are determined. The traditional and interactive forms and methods of educational work with schoolchildren, which provide an integral systematic approach to organization the process of formation national solidarity among school youth are presented. It is stated that the formation of national solidarity among school youth is defined as an organized subject-subject interaction, aimed at the spiritual development of the student's personality, her positive national feelings and national values that constitute the internal basis for national selfaffirmation readiness.

Key words: national solidarity, national identity, national values, school youth, Ukrainian nation, forms and methods of education.

Стаття надійшла до редакиії 22.03.2019 p. 